Pregledni članak

342.8:342.511(497.11)"2017"

doi:10.5937/zrpfns53-22467

Nevena D. Jovanović, Ph.D. Student

University of Novi Sad

Faculty of Law Novi Sad

nevena88jovanovic@yahoo.com

\title{
THE IMPACT OF ELECTION CAMPAIGN ON THE RESULTS OF PRESIDENTIAL ELECTIONS IN THE REPUBLIC OF SERBIA IN 2017
}

Abstract: Election campaigns, as essential political activities, receive great attention because of their potential to significantly influence voters, and therefore the final outcome of the electoral process. For precisely this reason, the election campaigns in the $21^{\text {st }}$ century are carefully planned and implemented. Taking into account all the elements and structure of the election campaign, special consideration should be given to media which are extremely powerful in terms of placing political messages and shaping public attitudes and opinions, particularly those of abstaining voters, first-time voters or voters not identifying with any party. In this respect, through a review of components of the election campaign, the paper aims to point to its importance and the impact it has on election results, with particular reference to the election campaign for presidential elections in the Republic of Serbia in 2017.

Keywords: election campaign, elections, election results, media, voters.

\section{INTRODUCTION}

Election campaign is an extremely complex activity running in certain sense even before the elections are called. It constitutes part of the electoral process, with its most active and for political subjects most important element being visible to the public as holder of the electoral right. During election campaigning, political subjects seek to influence the electorate and therefore the results of the electoral process. In this connection, the main task and goal of the paper is to determine the impact of the campaign for the election of President of the Republic of Serbia of 2017 on the voting results. The initial hypotheses of the paper are: that election 
campaign to a certain extent influences holders of election right because of citizens' loss of confidence in political office holders; the second hypothesis refers to the financial aspect of the subject of this paper, or to the statement that political campaigns involve outstanding spending from public and private sources for achieving the successful results; and finally, the third hypothesis refers to media strategy of political subjects during the election campaign and states that media campaign of political subjects influences voters' choices and that in the era of social networks and internet expansion media advertising does not necessarily need to incur the highest financial cost.

To determine the influence of the 2017 political campaign for the election of President of the Republic of Serbia on the voting results, the paper took into account political campaigns of 11 candidates. The importance of the paper is reflected in the recommendations and conclusions that will follow as a result of content analysis of official public authorities' data and reports by stakeholder organisations of the electoral administration during the election campaign ${ }^{1}$ as well as of the author's research conducted using the questionnaire technique. ${ }^{2}$

\section{THEORETICAL DEFINITION OF THE CONCEPT OF ELECTION CAMPAIGN}

Election campaign had been accorded great importance already in Ancient Rome, given its influence on the electorate and the election results, and this fact is attested by the „first preserved document on the campaign strategy, Commentariolum petitionis, dating back in $64 \mathrm{BC} .{ }^{\prime 3}$ It represents one of the key features of the electoral system becoming increasingly important with the introduction of the general voting right and the democratic multi-party elections. Although originally limited, the right to vote does exist in principle; all citizens enjoy equal right to form and express their political opinion, to associate into political parties and engage in the political battle. ${ }^{4}$ Political campaigns as they are known today have

${ }^{1}$ The data used in the analysis are the official data from the Republic Electoral Commission, Anti-corruption Agency (hereinafter: the Agency), Statistical Office of the Republic of Serbia and the reports of the Centre for Free Elections and Democracy, OSCE Office for Democratic Institutions and Human Rights, Lawyers' Committee for Human Rights, Centre for Research, Transparency and Accountability.

2 The conducted survey was based on descriptive method, and the technique applied was interview with 1060 citizens of the Republic of Serbia who participated in 2017 Presidential Elections using a questionnaire designed for this specific purpose.

${ }^{3}$ Tamaš Notari, „Izborni sistem i izborna kampanja u starom Rimu“, Zbornik radova Pravnog fakulteta u Novom Sadu, 45/2011, 514.

${ }^{4}$ Ljubomirka Krkljuš, „,Biračko pravo u aktima Srpskog narodnog pokreta u Južnoj Ugarskoj 1848-1849. godine“, Zbornik radova Pravnog fakulteta u Novom Sadu, 40/2006, 39. 
emerged at the outset of the $20^{\text {th }}$ century. Becoming aware of the influence that the campaign has on the voters during the elections, and taking into account its role and importance, political parties are paying the increasing attention to it in terms of its planning and implementation.

Election campaign means ,planned and organised political activity where election participants seek to gain maximum support from voters and thus win government power or secure participation in government power"5, or ,a set of activities by a political subject from the date of official announcement of elections to the date of proclamation of the final results of elections". ${ }^{6}$ It involves a variety of different actions and procedures carefully and meticulously planned in the period before elections are called, and from that day to the day of pronouncement of final results, implemented with the set objectives and strategy. During the election campaign, political actors present themselves to the voters who are left to choose, according to their own interests, beliefs and political orientation, those whom they consider would best exercise the political power in the state. Also, during the political campaign, voters are informed of the available electoral options. Finally, throughout the campaign, political candidates encourage the indifferent and undecided voters (occasional and new voters) ${ }^{7}$ to get involved in the political life and participate in the elections. In this way, it achieves its representational, instructional and educational functions.

Election campaign consists of a number of elements each of whose success directly affects the success of the political campaign. The elements of particular importance include: election headquarters organisation, internal and external analyses, election campaign plan, political activities, media strategy, organisation of activities during the electoral silence and on the Election Day, which will be described in more detail in the following sections.

\section{THE IMPACT OF ELECTION CAMPAIGN ON ELECTION RESULTS IN THE REPUBLIC OF SERBIA}

To ensure just and democratic elections and a level-playing field battle between political opponents, the issues related to electoral activities are regulated by the constitution, laws or regulations specifying the institutional rules for the electoral process. The success of the election campaign depends on a range of factors that determine its being more or less successful „,but there is no single factor which

\footnotetext{
${ }^{5}$ Dragan Kostović, „Izborni sistem”, Politička revija, 4/2008, 1269.

${ }^{6}$ Zakon o finansiranju političkih aktivnosti,Službeni glasnik RS, No. 43/2011 and 123/2014,
} Art. 2.

${ }^{7}$ See in, Mirjana Kasapović, Izborni Leksikon, Politička kultura, Zagreb 2003, 32-33. 
can decide an election single-handedly. Most importantly, each element of the 'political product' the party, the programme and the candidates - has a different impact." 8

Identifying the exact extent of the impact of the election campaign on election results is impossible. However, a causal relation between them clearly exists and in this regard the opinions diverge. On one side are those who believe that election campaigns manipulate voters, simplify political reality, encourage voters' apathy and contribute to democratic deficit in the long term. Standing on the other side are those who claim that campaigns have positive effects on electoral participation and voters' familiarity with political processes upon which they can make a rational voting decision and that attractive, media-honed campaigns can draw voter's attention. ${ }^{9}$ The truth is somewhere in between. For the election campaign activities to have a positive impact on election results it is necessary to think through the problems, needs and values that guide the voters - primarily because „before elections, voters have policy preferences and parties have policy offerings, and during the election, voters choose the best-fitting program to their own interests." 10

\subsection{The impact of election campaign on the results of presidential election in the Republic of Serbia in 2017}

Although presidential elections are more popular than local or parliamentary elections and are characterised by higher citizen interest, one can observe the downward turnout trend. Statistical data ${ }^{11}$ indicate that a bit more than one half of the total electorate actually participate in the elections. Research by the Social Sciences Institute shows that an ,absolute majority of citizens (57\%) have no interest in political topics and events." 12 Voters' abstention mostly results from distrust in political parties and the lack of interest in getting involved in the political life, wherefore during the election campaign candidates seek to foster citizens' political participation.

${ }^{8}$ Gerd Strohmeier, „How to Win in Modern Electoral Campaigning”, European View, 12/2013, 56 .

${ }^{9}$ See in, Marijana Grbeša,"Suvremene izborne kampanje i kako one utiču na demokratski proces“, Politička misao, 42/2005, 49-50.

${ }^{10}$ Annika Werner, „What voters want from their parties: Testing the promise-keeping assumption”, Electoral Studies, 57/2019, 187.

${ }^{11}$ In 2008 , the percentage of voters attending and voting in the elections was $61.37 \%$, in 2012 , it was $57.77 \%$, while in 2017 , the turnout fell to $54.34 \%$. Cited according to the data from the Statistical Office of the Republic of Serbia http://www.stat.gov.rs/sr-latn/oblasti/izbori/predsednicki-izbori/

12 J. Matić, „Populizam i medijska publika“, Građani Srbije i populizam: javno mnjenje Srbije 2017, (ed. Zoran Lutovac), Institut društvenih nauka, Beograd 2017, 132. 


\subsubsection{Election headquarters organisation, internal and external analyses}

The election headquarters is in most cases consisted of experts in the field of political organisation of political campaigns and political activists whose role gains importance in implementing electoral activities aimed at mobilising new party members and voters. Bearing in mind that 2017 Presidential Elections were ones to be held on a regular basis, political subjects had started preparing for them even before their announcement and public opinion surveys had been conducted by most political subjects because ,due to the general decline of trust in all political parties, the 'floating electorate' increases", making it necessary to conduct numerous public opinion surveys and „drawing on these data determine the content of concrete actions and their alterations in the course of the campaign". ${ }^{13}$ Of particular significance are surveys aimed to determine the balance of powers between the candidates, that is, to identify political positions of voters who will be voting in the elections, with the emphasis on whether and to what extent they decided whom they will give their support. On the basis of these results it is possible to predict the outcome of voting - ,if data indicate an uncertain outcome of the election race, surveys inspire mobilisation of voters and increase electoral participation; if data suggest certainty of the outcome of the election race, surveys inspire defeatism on the losing side, and lethargy on the winning side, thus decreasing electoral participation." 14 Public opinion surveys are not so accurate; political events that will mark the election campaign may produce changes in the political choice of voters. However, with an appropriate media campaign, the results of these researches can play a crucial role in the election campaign, „because its poll proved to be one of the ways of shaping and controlling the public opinion itself." 15 The analyses and results of surveys of political positions of voters that are conveyed through media can critically influence the voters who remain undecided whom to vote for in the elections.

Defining the political strategy and objectives of election campaign can largely be influenced by the results of internal and external analyses that form the basis for determining the political programme and plan of the election campaign. The strategy of the ruling political parties was well defined, as proved by the results achieved, unlike those of the opposition parties, whose success failed despite that certain parties had large funds available. One exception is Luka Maksimović, a candidate with the least funds, who managed to achieve a success greater than expected.

During the election campaign, the political actors used negative campaigning strategy with a tendency to point to amorality, incompetence and make a mockery

\footnotetext{
${ }^{13}$ Slobodan Vuksanović, Političke komunikacije, Prosveta, Beograd 2009, 15.

${ }^{14}$ M. Kasapović, Izborni Leksikon, Politička kultura, Zagreb 2003, 60.

${ }^{15}$ Ibid., 61.
} 
of what the rival candidate represents. However, „negative events are also less predictable and thus contain unexpected information, all of which enhances their attractiveness to newsmakers", ${ }^{16}$ so that the ,,counter-effect of the negative campaign is that the attacked candidates can benefit from the attack initiated by others"17, which was exactly the case when families of the political candidates were subjects of negative campaigns.

\subsubsection{Election campaign plan and carrying out political activities}

The election campaign plan means planning in advance for daily activities and objectives to be achieved for the duration of the election campaign. With certain political and social events being unpredictable, the election campaign plan is necessarily variable. Carrying out political activities (operational strategy) means implementing the political campaign plan and requires the intensive and dynamic implementation of activities planned for reaching the set objectives of the election campaign. The success of realising the planned political activities and objectives directly affects the outcome of the election campaign. The key role in this process is played by the activists of political subjects who throughout the campaign seek to present, using various means, to the electorate the political programme of the political party and motivate voters to participate in the electoral process by providing support. The implementation of political activities directly depends on the financial resources available to a political subject. Considering that, unlike the ruling party, the opposition had moderate budget funding allocated for the election campaign, most candidates were campaigning using various means of direct communication ${ }^{18}$ with citizens. „A phone call or a knock at the door is not only the best way to motivate people to vote and get involved, but it is also a good way to get to know the people, their interests and potential, for example by asking questions about their party preferences, frequency of voting, and contribution and policy interests. Clearly, canvassing is very time-consuming during a campaign, but it is worthwhile."19 Direct communication ensures better acquaintance of voters with the candidate and political party, their support, and, in this connection, influence on their political opinion and final electoral choice. The effect of direct communication with voters is them being better informed,

\footnotetext{
${ }^{16}$ Martin Haselmayer, Thomas M Meyer, Markus Wagner. „Fighting for Attention: Media Coverage of Negative Campaign Messages.” Party Politics, 25/ 2019, 413.

${ }^{17}$ Ljubiša Stojmirović, Aleksandra Stojković, Tomislav Nikolić, „Politički marketing - negativna kampanja“, Ekonomika, 60/2014, 95.

${ }^{18}$ It refers to already traditional means of communication including distribution of leaflets and other promotional electoral materials, communication at information stands, public gatherings, door-to-door campaigning, phone calls and so on.

${ }^{19}$ Markus Keschmann, „Reaching the Citizens: Door-to-Door Campaigning”, European View, $12 / 2013,96$.
} 
motivated and interested in elections, with reduced political apathy and a feeling of importance as a politically involved citizen. ${ }^{20}$

The spending by political candidates on the electoral materials amounted to $15.38 \%$ of the total spending designated for the election campaign. The ruling parties distributed more than half of the total informational brochures, newspapers, posters, and rented around $52 \%$ of all billdboards, while the opposition candidates distributed the most leaflets. For organising public events, political subjects spent $5.24 \%$ of the total election campaign spending. The ruling political parties organised 13 conventions of the possible 22, while most of the 11 public meetings were held by the opposition. During the presidential campaign, a number of gatherings in the form of public forums and discussions with citizens were also organised on the occasion of visits to important institutions and local communities, providing all candidates with the opportunity to communicate with voters and discuss various topics of particular concern to the citizens. Particularly active was the ruling party who organised two thirds of these events. ${ }^{21}$

The opposition, initially passive and limited in terms of funding, focused on communication with citizens through ,social networks and online advertising as well as public meetings and through electoral materials used in public places". ${ }^{22}$ The ruling parties who had significant financial support and support by a large number of political activists had been active from the very beginning to the very end of the campaign and had outstanding success in implementing political activities, all of which impacted on the election results.

\subsubsection{Media strategy}

For the political subjects to be able to convey their respective political programmes and messages to the electorate it was necessary to define media strategy, which meant to specify in detail which printed, radio, television and electronic media would be utilised in the electoral process and to what extent.

In reference to candidates' media presence, the content analysis of daily and weekly papers during the pre-election and election campaign suggests that $73 \%$ of the content centred on presidential candidates, that is, presidential elections. Candidate A. Vučić, who then held the Prime Minister position, had a prevailing presence in media, appearing in $58,8 \%$ of the total printed media. On this occasion, he was presented in positive light in $80.3 \%$ of them, in neutral light in $7,7 \%$ and

\footnotetext{
${ }^{20}$ See in, Richard F. Yalch, ,Pre-Election Interview Effects on Voter Turnout”, The Public Opinion Quarterly, 40/1976, 335.

${ }^{21}$ Izveštaj o troškovima izborne kampanje za izbor predsednika republike 2017. godine, Agencija za borbu protiv korupcije RS, Beograd, 2017, 10.

${ }^{22}$ Predsednički izbori 2017, Izveštaj Centra za slobodne izbore i demokratiju, Centar za slobodne izbore i demokratiju, Beograd, 2017, 32.
} 
in negative light in $8 \%$ of these media. Saša Janković, a candidate nominated by a group of citizens, appeared in $31.5 \%$ of the total printed media front pages. He was mostly presented in negative light (49.8\%), followed by $15 \%$ of pages in positive light and $35.4 \%$ reporting neutrally about him. Vuk Jeremić was presented negatively in $61 \%$ of the total media pages he appeared in. Other political participants in the elections were significantly less present, with the exception of Luka Maksimović, whose presence accounts for $10.36 \%$, of which he was presented in positive light in $65.4 \%$ of all pages, neutrally in $19.2 \%$ and in negative light in $15.4 \%$ of media pages. With respect to commercial advertisements, most funds were spent by candidates Vuk Jeremić and Aleksandar Vučić. ${ }^{23}$ Similar statistics was noted in television media.

The Anti-Corruption Agency's Report on Presidential Campaign Costs shows that political subjects spent most of the funds on media advertising $-73.65 \%$. They had promotions on radio and television, in printed and online media and on social networks. In this way, they placed, primarily by means of TV stations, 1187 political advertisements in total, of which the political messages of the candidate Aleksandar Vučić were dominant. From the Agency's data collected from monitoring the election campaign it was concluded that „candidate Luka Maksimović was widely present on social networks and online portals - however, this has to do with free publicity rather than paid ads" 24 , thus proving that a well thought out media strategy that does not incur much costs can positively impact on the election results. The presence of ruling parties, owing to their substantial funds designated for electoral advertising, continued to prevail through almost all media.

\subsubsection{Organisation of activities during the electoral silence and on the Election Day and election campaign evaluation}

Despite the statutory prohibition of any political activities during the electoral silence the political subjects were most active in this particular period seeking to achieve the campaign goals. Upon the completion of the electoral process and an unofficial record of data processing, some political subjects made an official address to the electorate.

While 2017 Presidential Elections could be predicted, with nearly absolute certainty, in terms of the winner, they were surprising in terms of the final result. ${ }^{25}$

${ }^{23}$ Compare Predsednički izbori 2017, Izveštaj Centra za istraživanje, transparentnost i odgovornost posmatračke misije, Beograd, 2017, 22-25

${ }^{24}$ Izveštaj o troškovima izborne kampanje za izbor predsednika republike 2017. godine, Agencija za borbu protiv korupcije RS, Beograd, 2017, 21.

${ }^{25}$ According to the Republic Electoral Commission's Report on the final results of elections for the president of the Republic, held on 2 April 2017, the results are as follows: Aleksandar Vučić $55.08 \%$, Saša Janković $16.36 \%$, and Luka Maksimović 9.43\%. Cited from http://www.rik.parlament. gov.rs/latinica/izbori-za-predsednika-republike-2017-konacni-2004.php 
The third-ranked Luka Maksimović, representative of a group of citizens, won more votes than other candidates who have been politically active longer than him. Also, one must not neglect that the financial power of this citizen group is much weaker than that of the representatives of the ruling and parties constituting the opposition. This movement's campaign is one example of the impact of election campaigns on election results. Well-conceived political messages conveyed through media to the selected target group made it possible for this candidate to achieve great success compared to most of the candidates. Many analysts ascribe this electoral success to effective drawing of attention of young absentees who had no serious interest in politics and of voters dissatisfied with the political candidates.

The success of the winning coalition in the presidential elections can be perceived as a result of the years-long successful campaigning. Leader of the ruling political party used citizens' trust gained during his term as a Prime Minister and stable and secure electorate of the political party he represents. By discharging political functions, political officials from the ruling political party were more present in the media during the election campaign. Also, the ruling political coalition has during the election campaign carried out a range of activities aimed at having the voter identify with the political party. The results of post-election public opinion survey show that ,nearly $53 \%$ of the respondents who expressed some party identification considered SNS as the party to which they have the strongest affiliation. No other party neared this proportion." ${ }^{26}$ Association with party identification had the effect of SNS evoking positive feelings with their followers, which facilitates its mobilisation of voters and success of the election campaign.

In the survey aimed to assess the influence of the 2017 Serbian Presidential Election Campaign on the election results, $47.3 \%$ respondents considered that election campaign affects election outcome to some extent, while $28 \%$ of them held that it affects it to a large extent; however, $77.8 \%$ of the respondents clearly stated that they had decided whom they would be voting for even before the beginning of the election campaign. With the current political conditions in mind, it is reasonable to ask whether the election campaign has any impact at all in the situation where the ruling political party becomes dominant and the multi-party system and democratic elections meaningless because „political opposition in Serbia has been consumed by a trend also prevailing in 'traditional' democracies - one of losing its ideological identity. Driven by desire to 'constructively get closer' to the 'reform course' of the government, the opposition is in fact blunting the edge of its essence to criticise the entire system. In that way, although unaware of it, it is drifting away from voters as it ceases to be the true alternative". ${ }^{27}$

${ }^{26}$ Bojan Todosijević, ,Populistički stavovi, izborna izlaznost i izborno opredeljivanje“, Građani Srbije i populizam: javno mnjenje Srbije 2017,(ur. Zoran Lutovac), Institut društvenih nauka, Beograd, 2017, 98 -100.

${ }^{27}$ Slobodan P. Orlović, „Ustav Srbije i prava opozicije“, Anali Pravnog fakulteta u Beogradu, 65/2017, 127-128. 


\section{THE ROLE OF MEDIA IN THE 2017 ELECTION CAMPAIGN FOR THE PRESIDENT OF THE REPUBLIC OF SERBIA}

Legal regulations governing the matter of media activities in the election campaign define principles and duties of media with a view to ensuring free, objective and accurate reporting on political subjects.

It can be said that normative framework concerning the duties and powers of media during the election campaign consists of the Act on Public Information and Media ${ }^{28}$, Electronic Media Act ${ }^{29}$, Public Media Services Act, ${ }^{30}$ Advertising Act ${ }^{31}$, byelaws, among which the one that stands out most is the Regulation on Duties of Media Service Providers in the Election Campaign and the General Binding Instruction on the Conduct of Broadcasters (Code of Conduct for Broadcasters), provides favourable conditions for equal media representation of political candidates during the election campaign. However, in the election practice it is often the case that legal rules are applied inappropriately. The capacity of the election campaign is mainly determined by financial and political power of the candidates, which leads to unequal representation of political ideas in media.

Aggressive media strategy is a feature of the modern election campaign, making the use of media in election campaigns paramount in several respects. „First, media are the main source of political information and thus the actor in the political education of citizens, previously done by political parties. Second, media have an increasing influence on shaping the political agenda. Third, commercialisation and tabloidisation of journalism by the dominant trends of personalisation of politics, sensationalism, scandals and dramatisation are conducive to the legitimisation and acceptance of populist messages." 32

Media, as essential means of public information, are irreplaceable participants in the political life in general, and particularly during the election campaign. Regarding the influence of media on shaping and forming public opinion, it can be stated that they have a key role and represent an exceptionally powerful means of election campaign. Although the internet and social networks in the 21 st century stand for an extremely powerful media resource growing in importance, television remains the medium with the greatest influence, while the interest in print media is gradually declining. The questionnaire survey has shown that $51.8 \%$ of the respondents consider that media influence voters' choices to a large extent, while $30.6 \%$ of them consider that they influence voters' choices to a certain extent.

28 „Službeni glasnik RS“, No. 83/2014, 58/2015 and 12/2016

${ }^{29}$ „Službeni glasnik RS““, No. 83/2014 and 6/2016

30 „Službeni glasnik RS“, No. 83/2014, 103/2015 and 108/2016

31 „Službeni glasnik RS“, No. 6/2016 and 52/2019

32 Jovanka Matić, „Populizam i medijska publika“, Građani Srbije i populizam: javno mnjenje Srbije 2017, (ed. Zoran Lutovac), Institut društvenih nauka, Beograd 2017, 131. 
Efforts by political actors to gain media sympathy derive from the fact that ,in structuring an advertising campaign, a candidate must anticipate not only his or her opponent's probable strategy but also the evolving behaviour of the news media." 33 However, one must not disregard the fact that a candidate's visibility in media depends on the financial power of the political party or the interest of citizens. The law provides that all media ,must generally ensure equal coverage of all submitters of electoral lists and candidates from those lists." ${ }^{34}$ While the public service media provider complied with these provisions, some private media did not deny their affinity to the ruling party, which makes acceptable the contention by the opposition political parties that the equality of all participants in the electoral process is not ensured. Although it is obvious that the ruling party „mainly owing to its being permeated with and related to the state, enjoys privileged position with respect to all four key points of mass media control (natural resources, ownership and funding, managerial and supervisory positions, content regulation)" 35 , on which basis it can be concluded that it dominates nearly all media, it is impossible to claim concurrently that the ruling party won the elections owing to its media domination.

The development of social media and their popularity among citizens (especially of young and middle age) had the effect that ,political campaigns, parties, and organisations are looking for new ways to mobilise supporters, particularly online by providing interactive spaces for participation and engagement." ${ }^{36}$ Social media were intensively used for communication with voters and placement of electoral messages, particularly because of being characterised by absence of media control and censorship and the content becomes viral in an instant.

Regulatory Authority for Electronic Media (hereinafter REM), as an independent regulatory organisation, is authorised to exercise public powers for the purpose of appropriate implementation of the defined policy in the provision of media services in the Republic of Serbia. ${ }^{37}$ However, given that the REM ,decided not to monitor comprehensively how electronic media with national coverage report on the election campaign" 38 , its role was reduced merely to overseeing media compliance with the provisions of the Advertising Act, ${ }^{39}$ while monitoring the

\footnotetext{
${ }^{33}$ Shanto Iyengar, Adam F. Simon, „New Perspectives and Evidence on Political Communication and Campaign Effects", Annual Review of Psychology, 51/2000, 162.

${ }^{34}$ Opšte obavezujuće uputstvo o ponašanju emitera ( Kodeks ponašanja emitera), ,Službeni glasnik RS“, No. 63/2007, Art. 12, para. 2.

${ }^{35}$ Ljiljana Baćević, „Mediji i rezultati izbora- da li je odnos kauzalan“, Psihologija, 29/1996, 63.

${ }^{36}$ Michael J. Jensen, ,Social Media and Political Campaigning: Changing Terms of Engagement?", The International Journal of Press/Politics, 22/2016, 25.

${ }^{37}$ Zakon o elektronskim medijima,"Službeni glasnik RS“, No. 83/2014 and 6/2016, Art 5.

${ }^{38}$ Predsednički izbori 2017., Izveštaj misije OEBS/KDILJP-a o proceni sprovođenja izbora, Kancelarija za demokratske institucije i ljudska prava, Varšava, 2017, 13.

${ }^{39}$ The role of REM was reduced to deciding on complaints against media activities during the election campaign, which number totalled to 32 during the campaign, on the basis of two of
} 
political contents in media in respect of elections reporting and ensuring compliance with legal provisions and possible sanctions for non-compliance completely failed.

By using social networks and the internet, the smaller and financially weaker political parties and not so popular candidates tried to overcome the fact of their insufficient presence in media space and attract the attention of voters and media to be able to inform them of their political programmes, activities and the results achieved. Media are necessary in the election campaigns of all political parties; however, they are not sufficient for winning them. Moreover, the electoral advertising programme is not preferred among the voters - it lasts too long, too much information about a great number of candidates is placed in the short time span, it is unattractive and monotonous.

\section{ELECTORAL CAMPAIGN FUNDING}

The matter of election campaign funding is regulated by the Act on Financing Political Activities. The implementation of all political activities during the election campaign, and in particular those relating to media campaigning, requires substantial funds which political parties, in accordance with law, raise from public or private sources. Candidates may use only private sources of funding in which case they must provide a surety bond as a guarantee which is not returned unless they win $1 \%$ of votes, or $0.2 \%$ in case a political subject is representing a national minority. A political subject who uses budget funds must return them if it fails to win the specified percentage of votes. ${ }^{40}$

Public, or budgetary funds allocated for covering presidential election campaign costs amount to $0.07 \%$ of the Republic of Serbia budgetary tax revenue ${ }^{41}$ while with respect to private revenues, natural persons can for purposes of regular operations provide political subjects with a maximum donation of 20 average monthly salaries, and legal entities with up to 200 average monthly salaries. ${ }^{42}$ The Act provides for public announcement of such donations, which means that smaller donations do not need to be published.

Anti-corruption Agency is empowered with the supervision and control of costs of election campaign. A political subject who participates in the election campaign must submit to the Agency a report on the election campaign costs within 30 days from the publication of final election results. ${ }^{43}$

which one advertising video spot by A. Vucic and six spots by candidate V.Jeremic were prohibitied due to violation of the Advertising Act.

${ }^{40}$ Zakon o finansiranju političkih aktivnosti, ,,Službeni glasnik RS”, No. 43/2011 and 123/2014, Art 2.

${ }^{41}$ Ibid., Art 20.

42 Ibid., Art. 10.

${ }^{43}$ Ibid., Art. 29. 
In the total financial resources of all political subjects who participated in the 2017 presidential campaign, a share of $62 \%$ relates to funds of the candidate A. Vučić, ${ }^{44}$ which derives from the fact that he had the largest public and private funds and that it refers to a coalition of 9 political parties. Miroslav Parović is the only candidate who used private funds, while Luka Maksimović and Saša Radulović are the only ones who used merely the budget funds. The campaign was funded by 7591 natural persons, the largest numbers of whom were supporting A. Vučić and the smallest number Nenad Čanak. ${ }^{45}$

The Agency's Report on presidential campaign costs shows that political subjects spent most funds on media advertising $-73.65 \%$. Most of the money was allocated for television advertising, followed by print media, social networks and the internet. The costs of electoral materials accounted for $15.38 \%$, those of public events $5.24 \%$, and other costs $5.73 \%$. A question arises whether election campaign must be this costly given that $49.6 \%$ of the population do not follow election campaign, and that $26.9 \%$ of them do so through social networks not requiring substantial financial costs. ${ }^{46}$

\section{CONCLUSION}

Election campaign as a political activity is an on-going process that never ends, which can be viewed to result from the nature of the political action, as the political opponents engage daily in the most diverse political activities aimed at winning the support of voters who, participating in political elections, decide whom to give their trust. The impact of election campaign on election results clearly exists; it is very difficult to establish its precise extent because it depends on numerous determinants.

Having in mind the above points we can confirm the hypothesis that election campaigns to a certain extent influence the voters and therefore the election results. Citizens make their decision on whom they will be voting for usually before the elections are called, while during the election campaign they remain indecisive regarding the political choices. Analyses and reports on 2017 Presidential Elections confirm the second hypothesis of the paper relating to the fact that political campaigns require substantial financial spending from public and private sources to achieve the effective results, however this is not sufficient for achieving good results. The third hypothesis that media largely influence voter choices constitutes simultaneously the reason behind allocating the largest share of funds to media

${ }^{44}$ Izveštaj o troškovima izborne kampanje za izbor predsednika republike 2017. godine, Agencija za borbu protiv korupcije RS, Beograd, 2017, 6.

${ }^{45}$ Ibid., 7.

${ }^{46}$ Data obtained from the author's research. 
advertising. That in the era of social networks and internet expansion media advertising does not have to affect to the largest extent the costs of election campaign is proved by the campaign of Luka Maksimović, a candidate whose budget for the election campaign was almost the smallest. This election campaign clearly is an indicator that with a good political strategy and political programme good results can be achieved. However, such cases are exceptional in political practice, as political campaigns require substantial financial resources, particularly for media advertising, for which reason the third hypothesis cannot be fully confirmed.

Statistical data showing that citizens due to the loss of confidence in holders of political functions do not follow the election campaign and electoral marketing provide basis for proposing a reduction of budgetary and private funds allocations for election campaigning and establishment of the maximum funds allowable for election campaign costs. This provision could, to certain extent, impact on financial equality of smaller and larger political parties in the electoral process. To ensure compliance with legal provisions governing the electoral process it is necessary to set up relevant institutions with competences, rights and duties clearly defined, that will be completely independent and autonomous and practice transparency in their work.

Election campaign comprises of a multitude of elements, all of which individually can contribute to a better final result. However, to win government power or secure a majority share in the exercise of power, it is necessary that views of candidates, that is, the political party on the one hand and voters on the other hand coincide. The current state of affairs in the Republic of Serbia reflects a substantially inferior status of the opposition relative to the political party in power, that is, that citizens do not perceive it as an appropriate alternative to the existing government. Open favouring of parties in power and their leaders, and marginalisation and negative presentation of representatives of the opposition have all contributed to the opposition being placed in a considerably less preferred position compared to the ruling government.

\section{REFERENCES}

Annika Werner, „What voters want from their parties: Testing the promise-keeping assumption", Electoral Studies, 57/2019, 186-195.

Bojan Todosijević, „Populistički stavovi, izborna izlaznost i izborno opredeljivanje“, Građani Srbije i populizam: javno mnjenje Srbije 2017,(ur. Zoran Lutovac), Institut društvenih nauka, Beograd 2017, 95-129.

Dragan Gostović, „Izborni sistem“, Politička revija, 4/2008, 1261- 1282.

Gerd Strohmeier, „How to Win in Modern Electoral Campaigning”, European View, 12/2013, 51-58.

Izveštaj o konačnim rezultatima izbora za predsednika republike, Službeni glasnik $R S$, br. 013-855/17. 
Izveštaj o troškovima izborne kampanje za izbor predsednika republike 2017. godine, Agencija za borbu protiv korupcije RS, Beograd, 2017.

Jovanka Matić, „Populizam i medijska publika“, Građani Srbije i populizam: javno mnjenje Srbije 2017, (ur. Zoran Lutovac), Institut društvenih nauka, Beograd 2017, 131-152.

Ljiljana Baćević, „Mediji i rezultati izbora - da li je odnos kauzalan“, Psihologija, 29/1996, 63-70.

Ljubiša Stojmirović, Aleksandra Stojković, Tomislav Nikolić, „Politički marketingnegativna kampanja“, Ekonomika, 60/2014, 94-98.

Ljubomirka Krkljuš, „Biračko pravo u aktima Srpskog narodnog pokreta u Južnoj Ugarskoj 1848-1849. godine“, Zbornik radova Pravnog fakulteta u Novom Sadu, 40/2006, 27-42.

Markus Keschmann, „Reaching the Citizens: Door-to-Door Campaigning.” European View, 12/2013, 95-101.

Marijana Grbeša, ,Suvremene izborne kampanje i kako one utiču na demokratski proces“, Politička misao, 42/2005, 49-59.

Martin Haselmayer, Thomas M. Meyer, Markus Wagner. „Fighting for Attention: Media Coverage of Negative Campaign Messages." Party Politics, 25/ 2019, 412-423.

Michael J. Jensen, Social Media and Political Campaigning: Changing Terms of Engagement? The International Journal of Press/Politics, 22/2016, 23-42.

Mirjana Kasapović, Izborni Leksikon, Politička kultura, Zagreb 2003.

Opšte obavezujuće uputstvo o ponašanju emitera (Kodeks ponašanja emitera), Službeni glasnik $R S$, br. 63/2007.

Predsednički izbori 2017. Izveštaj misije OEBS/KDILjP-a o proceni sprovođenja izbora, Kancelarija za demokratske intitucije i ljudska prava, Varšava, 2017.

Predsednički izbori 2017, Izveštaj Centra za instraživanje, transparentnost i odgovornost posmatračke misije, Beograd, 2017.

Predsednički izbori 2017. Izveštaj Centra za slobodne izbore i demokratiju, Centar za slobodne izbore i demokratiju, Beograd, 2017.

Richard F. Yalch, „Pre-Election Interview Effects on Voter Turnout” The Public Opinion Quarterly, 40/1976, 331-336.

Shanto Iyengar, Adam F. Simon, „New Perspectives and Evidence on Political Communication and Campaign Effects", Annual Review of Psychology, 51/2000, 149-169.

Slobodan Vuksanović, Političke komunikacije, Prosveta, Beograd 2009.

Slobodan P. Orlović, „Ustav Srbije i prava opozicije“, Anali Pravnog fakulteta u Beogradu, 65/2017, 113-130.

Tamaš Notari, „Izborni sistem i izborna kampanja u starom Rimu“, Zbornik radova Pravnog fakulteta u Novom Sadu, 45/2011, 509-525.

Zakon o elektronskim medijima, ,Službeni glasnik RS“, br. 83/2014 i 6/2016.

Zakon o finansiranju političkih aktivnosti, Službeni glasnik RS, br. 43/2011 i 123/2014. http://www.rik.parlament.gov.rs/latinica/izbori-za-predsednika-republike-2017-konacni-2004.php

http://www.stat.gov.rs/sr-latn/oblasti/izbori/predsednicki-izbori/

Nevena D. Jovanović, student doktorskih studija 
Univerzitet u Novom Sadu

Pravni fakultet u Novom Sadu

nevena88jovanovic@yahoo.com

\section{Uticaj izborne kampanje za predsednika Republike Srbije 2017. godine na rezultate izbora}

Sažetak: Izbornim kampanjama, kao osnovnim političkim aktivnostima, poklanja se velika pažnja zato što mogu uticati na birače, a samim tim i na konačan ishod izbornog procesa. Upravo iz tog razloga, izborne kampanje se u XXI veku pažljivo planiraju i realizuju. Imajući u vidu sve elemente $i$ strukturu izborne kampanje, neophodno je posebnu pažnju posvetiti medijima koji su izuzetno moćni u pogledu plasiranja političkih poruka i u oblikovanju stavova i mišljenja javnog mnjenja, posebno birača apstinenata, birača koji prvi put glasaju ili birača koji nisu indentifikovani ni sa jednom političkom partijom. U smislu navedenog, cilj rada je da se kroz prikaz sadržajnih delova izborne kampanje ukaže na njen značaj i uticaj koji ima na rezultate izbora, sa posebnim osvrtom na izbornu kampanju za predsedničke izbore u Republici Srbiji 2017. godine.

Ključne reči: izborna kampanja, izbori, rezultati izbora, mediji, birači.

Datum prijema rada: 10.07.2019. 